\title{
PENGARUH KANDUNGAN NITRAT DAN FOSFAT TERHADAP KELIMPAHAN DIATOM DI MUARA SUNGAI WULAN, DEMAK
}

\author{
The Effects of Nitrate and Phosphate Concentration on The Diatom Abundance at Wulan Estuary, Demak
}

\author{
Renny Diah Permatasari, Djuwito*), Irwani \\ Program Studi Manajemen Sumberdaya Perairan, Jurusan Perikanan \\ Fakultas Perikanan dan Ilmu Kelautan, Universitas Diponegoro \\ Jl. Prof. Soedarto, SH, Tembalang, Semarang, Jawa Tengah - 50275, Telp/Fax. +6224 7474698 \\ Email : rennydiahp@gmail.com
}

\begin{abstract}
ABSTRAK
Muara Sungai Wulan merupakan salah satu kawasan bermangrove yang masih tersisa di wilayah Pantai Utara Jawa Tengah. Perputaran nutrien yang ada di perairan ekosistem mangrove menjadikan ekosistem ini kaya akan unsur hara. Konsentrasi unsur hara berpengaruh terhadap kelimpahan biota yang ada di dalamnya termasuk diatom. Penelitian ini bertujuan untuk mengetahui pengaruh kandungan nitrat dan fosfat terhadap kelimpahan diatom. Penelitian ini dilaksanakan pada bulan April 2016. Metode yang digunakan adalah metode deskriptif dengan teknik stratified random sampling. Stasiun penelitian dibagi dalam 3 stasiun berdasarkan sebaran salinitas, kemudian setiap stasiun ditentukan 2 titik sampling. Pengambilan sampel diatom menggunakan plankton net dengan mesh size $25 \mu \mathrm{m}$. Pengukuran parameter fisika kimia perairan dilakukan bersamaan dengan pengambilan sampel diatom. Hasil analisis parameter fisika kimia air selama penelitian diperoleh temperatur air $\left(30-32^{\circ} \mathrm{C}\right)$, kecerahan $(20-32,5 \mathrm{~cm})$, kedalaman $(50-120 \mathrm{~cm})$, kecepatan arus $(0,03-0,125 \mathrm{~m} / \mathrm{s}), \mathrm{pH} 6$, oksigen terlarut $(5,00-7,48 \mathrm{mg} / \mathrm{l})$, salinitas $(10-25 \mathrm{ppt})$, nitrat $(0,80-2,00 \mathrm{mg} / \mathrm{l})$, fosfat $(0,18-0,86 \mathrm{mg} / \mathrm{l})$. Diatom yang teridentifikasi terdiri dari 15 genera. Kelimpahan diatom tiap stasiun berkisar antara 3800-5287 ind/l, keanekaragaman (1,771-2,294), keseragaman (0,719-0,894) dan dominansi (0,117-0,228). Hasil uji regresi linier berganda dan korelasi parsial menunjukkan bahwa konsentrasi nitrat lebih berpengaruh terhadap kelimpahan diatom dengan nilai 0,729 dibandingkan dengan konsentrasi fosfat dengan nilai -0,461.
\end{abstract}

Kata Kunci : Nitrat; Fosfat; Kelimpahan Diatom; Muara Sungai Wulan

\begin{abstract}
Wulan estuary is one of the mangrove areas in North Coast of Central Java. Nutrients cycle in aquatic mangrove ecosystem makes this ecosystem rich of nutrients. Nutrients concentration affect the abundance of organisms, including diatom. The research aimed to determine influence of nitrate and phosphate on the diatom abundance. The research was conducted in April 2016. The method research used descriptive method with stratified random sampling technique. The station was divided into 3 stations based on salinity distribution, then the station are determined 2 sampling points. Diatom sampling used plankton net mesh size $25 \mu \mathrm{m}$. Measurement of physical-chemical parameters and diatom sampling were conducted in same time. Analysis of physical-chemical parameters showed that water temperature during the study range 30 to $32^{\circ} \mathrm{C}$, turbidity 20 $32,5 \mathrm{~cm}$, depth 50-120 cm, current speed 0,03-0,125 m/s, pH 6, dissolved oxygen 5,00 - 7,48 mg/l, salinity 10 to $25 \mathrm{ppt}$, nitrate 0,80 to 2,00 $\mathrm{mg} / \mathrm{l}$, phosphate 0,18 to 0,86 $\mathrm{mg} / \mathrm{l}$. Diatoms were identified consists of 15 genera. Diatom abundance ranged from 3800-5287 ind/l, diversity 1,771 to 2,294, uniformity 0,719 to 0,894 and dominance 0,117 to 0,228. The results of multiple linear regression and partial correlation showed that nitrate concentration has more influence on the abundance of diatoms with a value 0,729 compared with concentration of phosphate with a value -0.461 .
\end{abstract}

Key Words: Nitrate; Phosphate; Diatom Abundance; The Estuary of Wulan

*) Penulis penanggungjawab

\section{PENDAHULUAN}

Terdapatnya mangrove di sepanjang aliran menuju hilir sungai Wulan menunjang fungsi ekologi sebagai daerah mencari makan (feeding grounds), daerah pemijahan (spawning grounds) dan daerah pengasuhan (nursery grounds). Ekosistem mangrove juga merupakan ekosistem yang memiliki fungsi dan peranan penting untuk menunjang keberlangsungan ekosistem pesisir lainnya. Perputaran nutrien yang ada di perairan ekosistem

${ }^{(C)}$ Copyright by Management of Aquatic Resources (MAQUARES) 
mangrove menjadikan ekosistem ini kaya akan unsur hara. Ketersediaan unsur hara dipengaruhi oleh kegiatan yang ada di sekitar area mangrove pada Sungai Wulan, seperti kegiatan tambak, dan hasil limbah domestik.

Konsentrasi unsur hara berpengaruh terhadap kelimpahan biota yang ada di dalamnya termasuk plankton. Diatom merupakan fitoplankton yang masuk dalam kelas Bacillariophyceae. Filum ini sering ditemukan di perairan karena persebarannya yang luas. Sehingga diatom dapat dijadikan indikator biologis untuk mengetahui kondisi suatu perairan. Menurut Boney (1979), bahwa kelimpahan diatom dapat dipengaruhi oleh unsur-unsur hara seperti Nitrat dan Fosfat. Nitrat $\left(\mathrm{NO}_{3}{ }^{-}\right)$merupakan zat hara utama yang dibutuhkan oleh diatom untuk tumbuh dan berkembang dengan baik. Besarnya kandungan nitrat yang ada pada perairan akan merangsang pertumbuhan bagi diatom, karena kandungan nitrat pada konsentrasi tertentu dapat memberikan kondisi tumbuh yang baik bagi diatom dan dapat menjadi racun di perairan apabila konsentrasi melebihi yang dibutuhkan.

Berdasarkan uraian di atas terdapat pengaruh yang ditimbulkan dari konsentrasi nitrat dan fosfat terhadap kelimpahan diatom. Oleh karena itu dalam penelitian ini akan dikaji mengenai pengaruh kandungan NitratFosfat terhadap kelimpahan diatom di perairan ekosistem mangrove pada muara Sungai Wulan.

\section{MATERI DAN METODE PENELITIAN}

Materi yang digunakan dalam penelitian ini adalah sampel air yang diambil dari perairan ekosistem mangrove muara sungai Wulan. Sampel air ini digunakan untuk menganalisa konsentrasi nitrat, fosfat, dan kelimpahan diatom. Variabel kualitas air yang diukur meliputi Temperatur air, kecerahan, kedalaman, kecepatan arus, salinitas, derajat keasaman $(\mathrm{pH})$ dan oksigen terlarut. Alat-alat yang digunakan dalam penelitian ini adalah plankton net $25 \mu \mathrm{m}$ untuk menyaring fitoplankton, terrmometer air raksa untuk mengukur suhu, secchi disk untuk mengukur kecerahan, bola arus untuk mengukur kecepatan arus, refraktometer untuk mengukur salinitas, $\mathrm{pH}$ paper untuk mengukur $\mathrm{pH}$, botol winkler untuk mengukur DO, spektrofotometer untuk mengukur $\mathrm{N}$ dan $\mathrm{P}$.

Metode yang digunakan dalam penelitian ini adalah metode deskriptif dengan teknik stratified random sampling. Metode stratified random sampling yaitu pengambilan sampel secara terstratifikasi dengan membagi populasi ke dalam kelompok-kelompok yang homogen. Sampling dilakukan dengan tiga kali pengulangan selama tiga minggu pada bulan April. Lokasi pengambilan sampel dibagi menjadi tiga stasiun salinitas yang terdiri dari: stasiun I 25-20\%, stasiun II 20-15\%, stasiun III 15-10\%, kemudian setiap stasiun ditentukan dua titik sampling secara random. Pengambilan sampel dilakukan dalam tiga kali pengulangan dengan tenggang waktu satu minggu.

Pengambilan sampel diatom dilakukan dengan menggunakan metode sampling pasif pada setiap stasiun yang terdapat dua titik sampling. Pengambilan sampel air untuk diatom dengan cara menyaring 100 liter air ke dalam plankton net menggunakan ember dan gayung tangkai panjang. Hasil dari penyaringan tersebut didapatkan sampel diatom sebanyak $50 \mathrm{ml}$. Setiap titik sampling didapatkan 1 botol sampel diatom. Kemudian sampel diatom dimasukkan ke dalam botol sampel dan dilakukan pengawetan menggunakan lugol 4\%. Jumlah sampel diatom selama tiga kali pengulangan yaitu 18 botol sampel diatom. Kelimpahan diatom dihitung menggunakan Sedgwick-Rafter, sedangkan identifikasinya menggunakan buku identifikasi plankton Sachlan (1982) dan Yamaji (1986).

Perhitungan jumlah plankton per liter, digunakan rumus APHA (1989), yaitu :

$$
\mathrm{N}=\frac{\mathrm{I}}{\mathrm{L}} \times \frac{\mathrm{P}}{\mathrm{p}} \times \frac{\mathrm{V}}{\mathrm{V}} \times \frac{\mathrm{I}}{\mathrm{W}}
$$

Keterangan :

$\mathrm{N}=$ Jumlah fitoplankton per liter

$\mathrm{T}=$ Luas gelas penutup $\left(\mathrm{mm}^{2}\right)$

$\mathrm{L}=$ Luas lapang pandang $\left(\mathrm{mm}^{2}\right)$

$\mathrm{P}=$ Jumlah fitoplankton yang tercacah

$\mathrm{p}=$ Jumlah lapang pandang yang diamati

$\mathrm{V}=$ Volume sampel fitoplankton yang tersaring $(\mathrm{ml})$

$\mathrm{v}=$ Volume sampel fitoplankton di bawah gelas penutup (ml)

$\mathrm{w}=$ Volume sampel fitoplankton yang disaring (liter)

Perhitungan Indeks keanekaragaman (H') menurut Shannon dan Weaver (1949) dalam Odum (1993) dengan formula sebagai berikut :

$$
\mathrm{H}^{r}=-\sum_{i=0}^{\mathrm{s}} \mathrm{PI} \ln \mathrm{P}
$$

Keterangan :

$\mathrm{H}^{\prime}=$ Indeks Keanekaragaman

$\mathrm{P}_{\mathrm{i}}=$ Suatu fungsi peluang untuk masing-masing bagian secara keseluruhan

$\mathrm{n}_{\mathrm{i}}=$ Jumlah individu jenis ke-i 
$\mathrm{N}$ = Jumlah individu total

Perhitungan Indeks keseragaman berdasarkan persamaan Odum (1993) adalah sebagai berikut:

$$
e=\frac{H^{\prime}}{\ln S}
$$

Keterangan:

$\mathrm{e}=$ indeks keseragaman

$\mathrm{H}^{\prime}=$ indeks keanekaragaman

$\mathrm{S}=$ jumlah jenis

Perhitungan Indeks Dominansi menggunakan Indeks Dominansi Simpson (Odum, 1993) dengan rumus sebagai berikut :

$$
C=\left(n_{i} / N\right)^{2}
$$

Keterangan:

$\mathrm{C}$ = Indeks dominansi

$\mathrm{n}_{\mathrm{i}}=$ Jumlah individu jenis ke- $\mathrm{i}$

$\mathrm{N}$ = Jumlah total individu

Setelah mendapatkan hasil data primer melalui sampling lapangan dan analisa laboratorium, data akan diolah menggunakan uji regresi berganda dan analisis korelasi parsial. Analisis regresi berganda digunakan untuk mengetahui besarnya hubungan dan pengaruh variabel bebas (independen) $X_{1}$ (konsentrasi nitrat) dan $X_{2}$ (konsentrasi fosfat) terhadap variabel tak bebas (dependen) Y (kelimpahan diatom). Korelasi parsial dilakukan untuk mengetahui seberapa besar masing- masing pengaruh dari variabel bebas (independen) $\mathrm{X}_{1}$ (konsentrasi nitrat) dan $\mathrm{X}_{2}$ (konsentrasi fosfat) terhadap variabel tak bebas (dependen) Y (kelimpahan diatom). Perangkat lunak yang digunakan untuk analisa data ini adalah SPSS versi 20.

\section{HASIL DAN PEMBAHASAN}

A. Hasil

Sungai Wulan merupakan cabang dari Kali Serang yang berhulu di Blora. Bagian hilir Sungai Wulan terbagi menjadi dua cabang yaitu Sungai Wulan Lama dan Sungai Wulan Baru yang terletak di Desa Menco. Lokasi stasiun I merupakan stasiun sampling yang mewakili muara bagian bawah. Stasiun ini terletak di dekat pantai dengan kisaran salinitas $25 \mathrm{ppt}-20$ ppt. Lokasi stasiun II merupakan stasiun sampling yang mewakili muara bagian tengah memiliki kisaran salinitas $20 \mathrm{ppt}-15$ ppt. Lokasi stasiun III merupakan stasiun sampling yang mewakili muara bagian atas memiliki kisaran salinitas $15 \mathrm{ppt}-10 \mathrm{ppt}$.

Hasil uji laboratorium terhadap konsentrasi nitrat di muara Sungai Wulan menunjukkan nilai berkisar antara 0,80-2,00 mg/l. Distribusi nilai konsentrasi nitrat di lokasi penelitian dapat dilihat pada Gambar 1 .

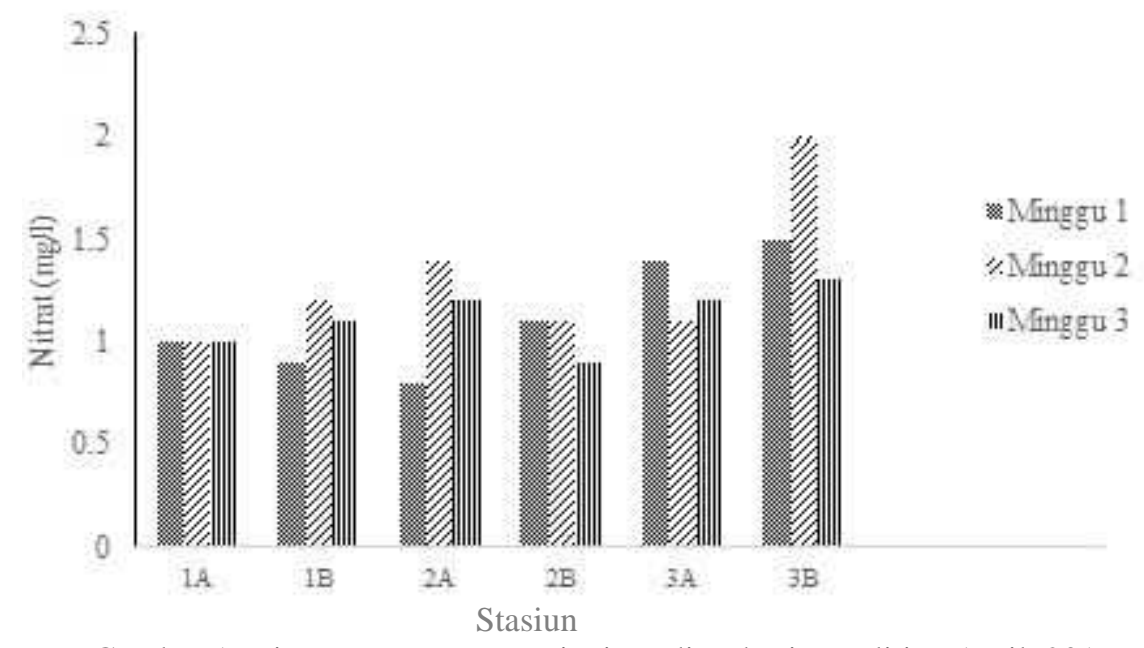

Gambar 1. Histogram Konsentrasi Nitrat di Lokasi Penelitian April, 2016 
Hasil uji laboratorium terhadap konsentrasi fosfat di muara Sungai Wulan menunjukkan nilai berkisar antara 0,18-0,86 mg/l. Distribusi nilai konsentrasi fosfat di lokasi penelitian dapat dilihat pada Gambar 2 .

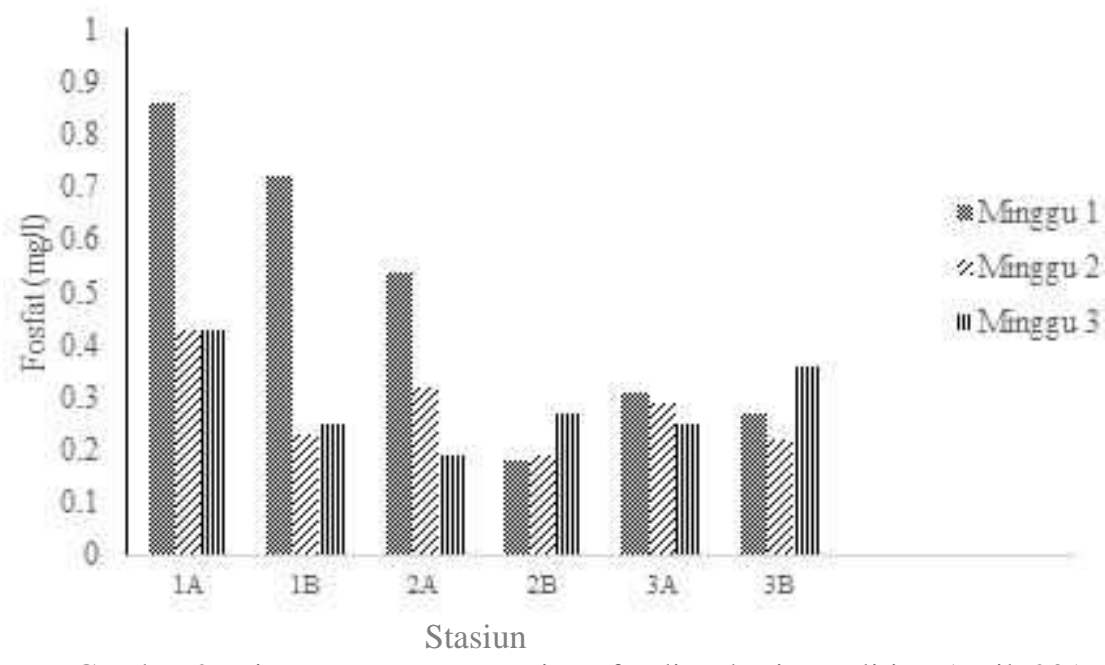

Gambar 2. Histogram Konsentrasi Fosfat di Lokasi Penelitian April, 2016

Kelimpahan Diatom, Indeks Keanekaragaman, Indeks Keseragaman, Indeks Dominansi

Berdasarkan hasil identifikasi yang telah dilakukan, diatom yang terdapat di muara Sungai Wulan terdiri dari 15 genera. Kelimpahan diatom tiap stasiun pada muara sungai Wulan berkisar antara 3800-5287 ind/1. Nilai indeks keanekaragaman berkisar antara 1,771-2,294. Nilai indeks keseragaman berkisar antara 0,719-0,894. Indeks dominansi yang diperoleh berkisar antara 0,117-0,228.

Tabel 1.Kelimpahan diatom,nilai indeks keanekaragaman (H'),indeks keseragaman(e) dan indeks dominansi (C)

\begin{tabular}{ccccc}
\hline Stasiun & Kelimpahan (Ind/l) & H' $^{\prime}$ & e & C \\
\hline I & $3822-4565$ & $2,035-2,294$ & $0,751-0,894$ & $0,117-0,145$ \\
II & $3800-5053$ & $1,899-2,288$ & $0,719-0,867$ & $0,120-0,225$ \\
III & $3842-5287$ & $1,772-1,923$ & $0,739-0,828$ & $0,177-0.228$ \\
\hline
\end{tabular}

\section{Pengaruh Nitrat dan Fosfat Terhadap Kelimpahan Diatom}

Hasil analisa didapat melalui analisis regresi berganda dengan nilai koefisien korelasi (R) sebesar 0,837 yang berarti hubungan nitrat dan fosfat terhadap kelimpahan diatom dikategorikan berhubungan kuat. Nilai koefisien determinasi $\left(\mathrm{R}^{2}\right)$ sebesar 0,701 nilai ini menunjukkan sebesar 70,1\% kelimpahan diatom dipengaruhi oleh konsentrasi nitrat dan fosfat, sisanya sebesar 29,9\% dipengaruhi oleh faktor lain seperti faktor fisika kimia pada perairan.

Tabel 2. Kesimpulan Model Analisis Regresi Berganda

\begin{tabular}{cccccc}
\hline Model & $R$ & $R^{2}$ & Adjusted $R^{2}$ & $\begin{array}{c}\text { Std. Error of the } \\
\text { Estimate }\end{array}$ & $\begin{array}{c}\text { Sig. } F \\
\text { Change }\end{array}$ \\
\hline 1 & 0,837 & 0,701 & 0,661 & 288,366 & 0,000 \\
\hline
\end{tabular}

Model regresi linier berganda diperoleh persamaan yaitu $Y=3289+1155$ nitrat -837 fosfat. Hasil analisis seperti yang disarikan tabel menunjukkan harga statistik untuk koefisien variabel $\mathrm{X}_{1}$ yaitu $\mathrm{t}_{\text {hit }}=4,121$ dan $\mathrm{p}$-value $=0,01 / 2=0,0005<0,05$ yang berarti nitrat berpengaruh positif terhadap kelimpahan diatom. Selanjutnya harga statistik untuk koefisien variabel $\mathrm{X}_{2}$ yaitu $t_{h i t}=-2,64$ dan $\mathrm{p}$-value $=0,062 / 2=0,031<0,05$ yang berarti fosfat berpengaruh positif terhadap kelimpahan diatom.

Tabel 3. Persamaan Regresi Linier Ganda

\begin{tabular}{|c|c|c|c|c|c|c|}
\hline \multirow[t]{2}{*}{ Model } & & \multicolumn{2}{|c|}{ Unstandardized Coefficients } & \multirow{2}{*}{$\begin{array}{c}\begin{array}{c}\text { Standardized } \\
\text { Coefficients }\end{array} \\
\text { Beta }\end{array}$} & \multirow[t]{2}{*}{$\mathbf{t}$} & \multirow[t]{2}{*}{ Sig. } \\
\hline & & $\mathbf{B}$ & Std. Error & & & \\
\hline \multirow{3}{*}{1} & (Diatom) & 3288,529 & 421,019 & & 7,811 & 0,000 \\
\hline & nitrat & 1155,486 & 280,399 & 0,648 & 4,121 & 0,001 \\
\hline & fosfat & $-837,057$ & 415,782 & $-0,317$ & $-2,013$ & 0,062 \\
\hline
\end{tabular}

Hasil analisa korelasi parsial memberikan petunjuk bahwa koefisien korelasi parsial yang lebih besar memberikan pengaruh yang lebih besar terhadap kriterion. Keeratan hubungan atau pengaruh antara variabel

${ }^{(\mathcal{C}}$ Copyright by Management of Aquatic Resources (MAQUARES) 
bebas $\left(\mathrm{X}_{1}\right)$ terhadap variabel terikat $(\mathrm{Y})$ yaitu dengan nilai 0,729 jauh lebih besar dibandingkan dengan keeratan hubungan atau pengaruh antara variabel bebas $\left(\mathrm{X}_{2}\right)$ terhadap variabel terikat $(\mathrm{Y})$ dengan nilai $-0,461$. Hal ini menunjukkan bahwa konsentrasi nitrat memiliki pengaruh yang lebih besar terhadap kelimpahan diatom dibandingkan dengan konsentrasi fosfat.

Tabel 4. Hasil Korelasi Parsial Konsentrasi Nitrat Terhadap Kelimpahan Diatom

\begin{tabular}{lllrr}
\hline & \multicolumn{2}{c}{ Variabel Kontrol } & diatom & nitrat \\
\hline & & Korelasi & 1,000 & 0,729 \\
& Diatom $(Y)$ & Signifikasi (1-tailed) &. & 0,000 \\
Fosfat $\left(\mathrm{X}_{2}\right)$ & Df & 0 & 15 \\
\cline { 2 - 5 } & & Korelasi & 0,729 & 1,000 \\
& \multirow{3}{*}{ Nitrat $\left(\mathrm{X}_{1}\right)$} & Signifikasi (1-tailed) & 0,000 &. \\
& & Df & 15 & 0 \\
\hline
\end{tabular}

Tabel 5. Hasil Korelasi Parsial Konsentrasi Fosfat Terhadap Kelimpahan Diatom

\begin{tabular}{rllrr}
\hline & \multicolumn{2}{c}{ Variabel Kontrol } & diatom & \multicolumn{1}{c}{ fosfat } \\
\hline & & Korelasi & 1,000 & $-0,461$ \\
\multirow{3}{*}{ Nitrat $\left(\mathrm{X}_{1}\right)$} & Diatom $(\mathrm{Y})$ & Signifikasi (1-tailed) &. & 0,031 \\
& & Df & 0 & 15 \\
\cline { 2 - 5 } & \multirow{3}{*}{ Fosfat $\left(\mathrm{X}_{2}\right)$} & Korelasi & $-0,461$ & 1,000 \\
& Signifikasi (1-tailed) & 0,031 &. \\
& & Df & 15 & 0 \\
\hline
\end{tabular}

\section{Parameter Fisika dan Kimia Muara Sungai Wulan}

Hasil pengukuran parameter fisika kimia muara sungai Wulan selama penelitian yaitu, temperatur air $30-$ $32{ }^{\circ} \mathrm{C}$, kecerahan $20-32,5 \mathrm{~cm}$, kedalaman $50-120 \mathrm{~cm}$, kecepatan arus 0,025-0,125 m/s, DO $5-7,48 \mathrm{mg} / \mathrm{l}$, salinitas berkisar antara $10 \mathrm{ppt}-25 \mathrm{ppt}$ dan nilai $\mathrm{pH} 6$ di semua titik sampling.

\section{B. Pembahasan}

\section{Konsentrasi Nitrat $\left(\mathrm{NO}_{3}{ }^{-}\right)$}

Konsentrasi nitrat di muara Sungai Wulan menunjukkan kandungan nitrat berkisar antara 0,80 - 2,00 $\mathrm{mg} / \mathrm{l}$. Nilai tersebut sesuai dengan yang dikemukakan oleh Mackentum (1969) dalam Yuliana dan Tamrin (2007), bahwa untuk pertumbuhan optimal fitoplankton memerlukan kandungan nitrat pada kisaran 0,9 - 3,5 $\mathrm{mg} / \mathrm{l}$.

Kandungan nitrat di perairan muara Sungai Wulan masih sesuai dengan kandungan nitrat yang dijumpai di perairan muara. Konsentrasi nitrat yang rendah terdapat pada stasiun I B dengan nilai 0,90 mg/l sedangkan konsentrasi nitrat tertinggi terdapat pada stasiun III B dengan nilai 2,00 mg/l. Hal ini terjadi dikarenakan pada stasiun I B memiliki kedalaman paling rendah dan pada stasiun III B memiliki kedalaman paling tinggi diantara stasiun yang lain. Menurut Hutagulung dan Rozak (1997) dalam Risamasu dan Prayitno (2011), kadar nitrat semakin tinggi bila kedalaman bertambah, sedangkan untuk distribusi horisontal kadar nitrat semakin tinggi menuju ke arah pantai. Konsentrasi nitrat di lapisan permukaan lebih rendah disebabkan karena banyak dimanfaatkan dan dikonsumsi oleh fitoplankton.

Faktor lingkungan yang lain yang menyebabkan tingginya angka konsentrasi nitrat yaitu oksigen terlarut dan nilai $\mathrm{pH}$. Nilai $\mathrm{pH}$ dan oksigen terlarut berpengaruh terhadap kecepatan nitrifikasi. Nilai $\mathrm{pH}$ pada lokasi penelitian bernilai sama yaitu 6 dan oksigen terlarut sebesar 5,00 - 7,48 mg/l. Menurut Effendi (2003), nitrifikasi berjalan secara optimum pada $\mathrm{pH} 8$ dan pada $\mathrm{pH}<7$ berkurang secara nyata.

\section{Konsentrasi Fosfat ( $\left.\mathrm{PO}_{4}^{-}\right)$}

Konsentrasi fosfat di muara Sungai Wulan menunjukkan bahwa kandungan fosfat berkisar antara 0,18 $0,86 \mathrm{mg} / \mathrm{l}$. Kandungan fosfat tersebut dikatakan layak pada lingkungan perairan. Nilai konsentrasi fosfat sesuai dengan yang dikemukakan oleh Mackentum (1969) dalam Yuliana dan Tamrin (2007), bahwa kandungan ortofosfat yang optimum untuk pertumbuhan fitoplankton adalah 0,09-1,80 mg/l.

Konsentrasi fosfat pada setiap stasiun menunjukkan nilai yang berbeda. Perbedaan konsentrasi fosfat diduga karena adanya pengaruh dari aktivitas di sekitar lokasi penelitian seperti kegiatan pertambakan di sepanjang aliran muara Sungai Wulan. Konsentrasi fosfat tertinggi pada stasiun I A dengan nilai 0,86 mg/l dan konsentrasi terendah pada stasiun II B dengan nilai $0,18 \mathrm{mg} / \mathrm{l}$.

Tingginya konsentrasi fosfat pada stasiun I A dapat disebabkan karena area tersebut lebih dangkal dan merupakan daerah pencampuran massa air secara langsung. Menurut Simanjuntak (2006), bahwa tingginya kadar fosfat disebabkan arus dan pengadukan massa air yang mengakibatkan terangkatnya kandungan fosfat yang tinggi dari dasar ke lapisan permukaan. Hal ini juga dikemukakan oleh Muchtar (2012), bahwa fenomena 
ini lumrah terjadi karena dasar perairan selalu kaya akan zat hara, selain berasal dari dasar perairan itu sendiri, juga dari sumbangan dekomposisi detritus dan mangrove yang ada di sekitar perairan.

\section{Jenis dan Kelimpahan Diatom}

Jenis diatom yang terdapat di muara Sungai Wulan terdiri dari 15 genera. Diatom yang terindentifikasi antara lain Asterionella sp., Bacteriastrum sp., Biddulphia sp., Chaetoceros sp., Coscinodiscus sp., Gyrosigma sp., Hemiaulus sp., Nitzschia sp., Pleurosigma sp., Rhizosolenia sp., Skeletonema sp., Stephanopyxis sp,. Thalassionema sp., Thalassiosira sp., dan Thalassiothrix sp.

Kelimpahan diatom setiap minggunya dapat terlihat bahwa jenis yang berlimpah yaitu dari genera Nitzschia sp., dan Skeletonema sp. Nitzschia sp. berperan cukup penting dalam menjaga kelangsungan ekosistem perairan. Nitzschia sp. merupakan salah satu spesies yang memiliki toleransi dan adaptasi yang tinggi terhadap lingkungan perairan sehingga dapat hidup pada lingkungan yang tercemar sekalipun. Menurut Widianingsih (2011), Nitzschia sp. mempunyai peran yang penting dalam ekosistem perairan sebagai produsen primer dan dapat digunakan sebagai pakan alami bagi organisme laut.

Berlimpahnya Skeletonema sp. terlihat pada setiap stasiun pengambilan sampel karena Skeletonema sp. mampu beradaptasi pada kisaran salinitas yang luas. Menurut Isnansetyo dan Kurniastuty (1995) dalam Rudiyanti (2011), bahwa Skeletonema costatum merupakan diatom yang bersifat euryhaline dengan kisaran 20$30 \%$ merupakan kisaran yang baik untuk pertumbuhan dan optimal pada 25-29\% namun dapat bertahan hidup hingga $40 \%$. Pertumbuhan Skeletonema sp. dipengaruhi oleh ketersediaan nutrien yang terdapat di lingkungan. Faktor yang berpengaruh antara lain adalah suhu, $\mathrm{pH}$, intensitas cahaya, dan yang sangat penting adalah faktor salinitas (Rudiyanti, 2011).

Genus Bacteriastrum sp. pada tabel hasil tidak ditemukan pada kisaran salinitas rendah yaitu stasiun II dan III hal ini disebabkan karena Bacteriastrum sp. merupakan jenis diatom laut yang biasanya terdapat pada kisaran salinitas $>20 \%$. Seperti yang dikatakan Purwanti et al.,(2012) bahwa nilai salinitas yang cukup tinggi $(>20 \%$ ) menyebabkan banyak ditemukannya jenis plankton air laut seperti Bacteriastrum sp.

Genus Hemiaulus sp., Gyrosigma sp. dan Thalassiosira sp. juga jarang ditemukan pada kisaran salinitas yang rendah pada stasiun II dan III. Selain adanya faktor habitat yang tidak sesuai faktor arus perairan juga berperan dalam penyebaran diatom. Menurut Hawkes (1978) dalam Suryanti (2008), bahwa kecepatan arus akan berperan dalam proses migrasi dan penyebaran plankton sebagai organisme yang pasif sehingga pergerakannya sangat ditentukan oleh arus. Hal ini berarti kecepatan arus akan mempengaruhi komposisi dan kelimpahan plankton.

\section{Indeks Keanekaragaman, Keseragaman dan Dominansi Diatom}

Nilai indeks keanekaragaman diatom pada semua stasiun dan setiap pengulangannya memiliki nilai indeks sedang. Pada minggu pertama memiliki nilai 1,771-2,288, minggu kedua memiliki nilai 1,907-2,294, dan minggu ketiga memilki nilai 1,857-2,162. Oleh karena itu dapat disimpulkan pada muara Sungai Wulan di semua stasiun tiap minggunya termasuk stabil moderat. Hal tersebut didasarkan pada pernyataan Odum (1993), bahwa kisaran nilai indeks keanekaragaman 0-1 menunjukkan bahwa daerah tersebut terdapat tekanan ekologis yang tinggi dan indeks keanekaragaman spesies rendah. Kisaran 1-3 menunjukkan indeks keanekaragaman sedang, untuk nilai keanekaragaman yang lebih besar dari 3 menunjukkan keadaan suatu daerah yang mengalami tekanan ekologi rendah dan indeks keanekaragaman spesiesnya tinggi.

Nilai indeks keseragaman diatom pada semua stasiun dan setiap pengulangannya tergolong merata. Pada minggu pertama memiliki nilai 0,739-0,867, minggu kedua memiliki nilai 0,802-0,894, dan pada minggu ketiga memiliki nilai 0,719-0,819. Hasil tersebut menandakan bahwa setiap jenis diatom tergolong merata. Menurut Pirzan et al. (2005), apabila keseragaman mendekati nol, berarti keseragaman antar spesies di dalam komunitas tergolong rendah dan sebaliknya keseragaman yang mendekati satu dapat dikatakan keseragaman antar spesies tergolong merata atau sama.

Nilai indeks dominansi pada semua stasiun dan tiga pengulangan pengamatan menunjukkan nilai mendekati nol (0), nilai tersebut menunjukkan bahwa tidak ada jenis diatom yang mendominasi pada lokasi sampling. Apabila nilai dominansi mendekati nilai 1 berarti di dalam komunitas terdapat spesies yang mendominansi spesies lainnya, sebaliknya apabila mendekati nilai 0 berarti di dalam struktur komunitas tidak terdapat spesies yang secara ekstrim mendominasi spesies lainnya (Basmi, 2000).

\section{Pengaruh Nitrat dan Fosfat Terhadap Kelimpahan Diatom}

konsentrasi nitrat dan fosfat di muara Sungai Wulan memiliki nilai yang berkisar antara 0,80-2,00 mg/l dan $0,18-0,86 \mathrm{mg} / \mathrm{l}$. Konsentrasi nitrat cenderung mengalami kenaikan pada setiap stasiun dan mengalami kenaikan yang signifikan pada stasiun III hingga mencapai angka 2,00 mg/l. Berbeda halnya dengan stasiun I yang memiliki nilai konstan pada setiap minggunya. Kenaikan konsentasi nitrat juga diiringi dengan melimpahnya diatom pada stasiun III dengan total mencapai $27.899 \mathrm{ind} / \mathrm{l}$.

Menurut Handoko et al.,(2013) pola persebaran fitoplankton menunjukkan adanya keterkaitan dengan sebaran nitrat. Kelimpahan fitoplankton semakin besar sejalan dengan peningkatan kandungan nitrat. Hal ini juga dikemukakan oleh Mackentum (1969) dalam Yuliana dan Tamrin (2007), bahwa untuk pertumbuhan 
optimal fitoplankton memerlukan kandungan nitrat pada kisaran 0,9-3,5 mg/l. Secara lebih khusus Parson et al., (1984) dalam Handoko et al.,(2013) menjelaskan bahwa kebutuhan minimum nitrat yang dapat diserap oleh diatom berkisar 0,001-0,007 mg/l.

Berdasarkan hasil pengukuran fosfat, konsentrasi fosfat tertinggi terdapat pada stasiun I yaitu $0,86 \mathrm{mg} / \mathrm{l}$, tetapi hal tersebut tidak diiringi oleh kenaikan kelimpahan diatom. Menurut Hasrun et al.,(2013) bahwa tingginya kandungan fosfat disebabkan pemanfaatan fosfat oleh diatom kurang optimal yang dapat dilihat dengan rendahnya kelimpahan diatom. Meningkatnya populasi fitoplankton dapat menurunkan kadar fosfat dalam suatu perairan.

Hal ini berarti kelimpahan fitoplankton pada perairan dipengaruhi oleh nutrien nitrat dibandingkan dengan fosfat. Nitrat merupakan faktor penentu dari kelimpahan fitoplankton. Pengaruh nutrien terhadap fitoplankton pada kenyataannya tidak selalu diikuti oleh peningkatan kelimpahan dari plankton, hal ini disebabkan oleh komposisi unsur hara yang tidak sesuai kebutuhan plankton, keberadaan unsur hara yang tidak mampu bertahan terhadap kondisi atau tingkat optimal bagi produktivitas perairan, dan terjadi penyuburan yang berlebih akibat adanya beban masukan unsur hara dari daratan atau sungai (Basmi, 1995 dalam Handoko et al.,2013).

Data yang diolah menggunakan uji regresi linier berganda dengan selang kepercayaan 95\% memberikan informasi bahwa konsentrasi nitrat dan fosfat berhubungan kuat dengan nilai 0,837 dengan koefisien determinasi sebesar 0,701. Hal ini berarti sebesar 70,1\% kelimpahan diatom dipengaruhi oleh konsentrasi nitrat dan fosfat dan 29,9\% lainnya dipengaruhi oleh parameter fisika kimia di sekitar lingkungan perairan.

Berdasarkan hasil analisa korelasi parsial diperoleh pengaruh konsentrasi nitrat terhadap kelimpahan diatom yaitu sebesar 0,729 sedangkan pengaruh konsentrasi fosfat terhadap kelimpahan diatom yaitu sebesar 0,461. Hal ini menunjukkan bahwa konsentrasi nitrat lebih berpengaruh terhadap kelimpahan diatom dibandingan dengan konsentrasi fosfat.

\section{Parameter Fisika dan Kimia Muara Sungai Wulan}

Temperatur perairan selama penelitian berkisar antara 30-32 $\mathrm{C}$. Nilai termperatur air tersebut diduga adanya pengaruh dari cuaca dan waktu pengukuran. Suhu memiliki pengaruh yang kuat pada fungsi fisiologis. Suhu yang tinggi akan mempengaruhi proses metabolisme, menaikkan kecepatan perubahan sel, respirasi, dan mempengaruhi pergerakan diatom karena adanya perubahan viskositas sitoplasma di dalam rafe. Suhu yang berhubungan dengan faktor iklim lainnya merupakan variabel yang menentukan pengontrolan kelimpahan dan distribusi diatom (Yuliana, 2007 dalam Sulaiman, 2012).

Nilai kecerahan pada setiap stasiun berkisar antara 20-32,5 cm. Keberadaan cahaya berpengaruh terhadap kehidupan diatom sebagai produsen primer di perairan laut. Cahaya matahari berfungsi untuk membantu diatom melakukan fotosintesis. Keberadaan diatom hanya terdapat pada kedalaman tertentu dengan intensitas cahaya yang masih memungkinkan untuk berfotosintesis. Kedalaman optimum bagi diatom untuk melakukan fotosintesis berkisar 5-20 m (Boney, 1979).

Kedalaman setiap stasiun diperoleh hasil yang berbeda-beda. Pada stasiun I berkisar antara $50-78 \mathrm{~cm}$, stasiun II berkisar antara $68-85 \mathrm{~cm}$, dan stasiun III berkisar antara 80-120 cm. Nilai kedalaman yang berbeda menunjukkan adanya perbedaan kontur dan topografi pada setiap segmen muara Sungai Wulan. Kedalaman juga dipengaruhi oleh dinamika pasang surut air laut dan massa air dari hilir. Hutabarat dan Evans (2012), menyatakan bahwa kedalaman mempunyai hubungan yang erat terhadap stratifikasi suhu vertikal, penetrasi cahaya, densitas dan kandungan oksigen serta unsur-unsur hara.

Kecepatan arus di muara Sungai Wulan berkisar antara 0,03-0,2 m/s. Kecepatan arus di muara Sungai Wulan cenderung tenang yang dipengaruhi oleh pergerakan massa air dari hulu, lalu lalang kapal nelayan, pasang surut dan cuaca atau kecepatan angin pada saat pengambilan sampel.

Arus mempunyai arti yang sangat penting dalam menentukan pergerakan dan distribusi plankton pada suatu perairan. Pergerakan (migrasi) plankton terjadi secara vertikal pada beberapa lapisan perairan, tetapi kekuatan renangnya sangat kecil jika dibandingkan dengan kekuatan arus pada perairan tersebut (Hutabarat dan Evans, 2012).

Derajat keasaman $(\mathrm{pH})$ di muara Sungai Wulan pada setiap stasiun dan setiap minggunya mendapat nilai yang sama yaitu 6. Nilai tersebut menunjukkan bahwa perairan muara Sungai Wulan masih berada di bawah batas optimal bagi pertumbuhan organisme.

Derajat keasaman $(\mathrm{pH})$ dan nilai konsentrasi basa (alkalinitas) mempengaruhi proses fisiologi diatom, sehingga perubahannya mempengaruhi pertumbuhan diatom. Nilai $\mathrm{pH}$ yang dibutuhkan untuk mendukung pertumbuhan sel diatom berkisar antara 7-9 dengan nilai optimum berkisar antara 8,2-8,7. Nilai pH yang optimal sangat penting untuk proses fisiologis sel diatom (Barsani dan Gualtieri, 2006 dalam Sulaiman, 2012).

Oksigen terlarut (DO) yang terukur pada muara Sungai Wulan berkisar antara 5,00-7,48 mg/l. Nilai ini masih baik bagi kehidupan diatom. Menurut Reynolds (1990) dalam Hariyati (2009), bahwa diatom mampu hidup pada tingkat kelarutan oksigen antara 7 sampai $12 \mathrm{mg} / \mathrm{l}$, tetapi ada beberapa jenis yang mampu hidup pada konsentrasi oksigen di bawah $6,5 \mathrm{mg} / \mathrm{l}$, karena itu diatom dapat dijadikan sebagai indikator perairan tercemar.

\footnotetext{
() Copyright by Management of Aquatic Resources (MAQUARES)
} 
Menurut Odum (1993), oksigen terlarut (DO) masih baik bagi organisme perairan selama tidak kurang dari 4 $\mathrm{mg} / \mathrm{l}$.

Salinitas selama pengamatan di perairan muara Sungai Wulan berkisar antara 10-25\% \% . Menurut Nybakken (1992), bahwa salinitas merupakan faktor yang sangat penting bagi pertumbuhan plankton. Perubahan salinitas menyebabkan plankton mempertahankan keseimbangan tekanan osmosis antara protoplasma dengan perairan. Oleh karena itu, salinitas dapat mempengaruhi kelimpahan dan distribusi plankton.

\section{KESIMPULAN}

Berdasarkan hasil penelitian yang telah dilakukan, dapat disimpulkan bahwa :

1. Konsentrasi nitrat pada masing-masing stasiun di muara Sumgai Wulan, Demak berada dalam kisaran 0,80-2,00 mg/l. Stasiun I A 1,0 mg/l, stasiun I B 0,90-1,10 mg/l, stasiun II A 0,80-1,40 mg/l, stasiun II B 0,90-1,10mg/l, stasiun III A 1,10-1,40 mg/l dan stasiun III B 1,30-2,00 mg/l. Sedangkan konsentrasi fosfat berada dalam kisaran 0,18-0,86 mg/l. Stasiun IA 0,43-0,86 mg/l, stasiun I B 0,23-0,72 mg/l, stasiun II A 0,19-0,54 mg/l, stasiun II B 0,18-0,27 mg/l, stasiun III A 0,25-0,31 mg/l, dam stasiun III B 0,22-0,38 $\mathrm{mg} / \mathrm{l}$.

2. Jenis diatom yang teridentifikasi terdiri dari 15 genera yaitu Asterionella sp., Bacteriastrum sp., Biddulphia sp., Chaetoceros sp., Coscinodiscus sp., Gyrosigma sp., Hemiaulus sp., Nitzschia sp., Pleurosigma sp., Rhizosolenia sp., Skeletonema sp., Stephanopyxis sp,. Thalassionema sp., Thalassiosira sp., dan Thalassiothrix sp. Kelimpahan diatom tiap stasiun berkisar antara 3800-5287 ind/l. Indeks keanekaragaman berkisar antara 1,771-2,294. Indeks keseragaman berkisar antara 0,719-0,894. Indeks dominansi berkisar antara 0,117-0,228.

3. Hasil uji regresi linier berganda menunjukkan adanya hubungan erat antara konsentrasi nitrat dan fosfat terhadap kelimpahan diatom sebesar 0,837 dengan koefisien determinasi sebesar 0,701. Hal ini menunjukkan bahwa 70,1\% kelimpahan diatom dipengaruhi oleh konsentrasi nitrat dan fosfat dan 29,9\% lainnya dipengaruhi oleh parameter fisika kimia di sekitar lingkungan perairan. Hasil uji korelasi parsial menunjukkan bahwa konsentrasi nitrat lebih berpengaruh terhadap kelimpahan diatom dengan nilai 0,729 dibandingan dengan konsentrasi fosfat dengan nilai -0,461.

\section{UCAPAN TERIMAKASIH}

Penulis mengucapkan terima kasih kepada Dr. Ir. Bambang Sulardiono, M.Si, Ir. Siti Rudiyanti, M.Si dan Churun Ain, S.Pi, M.Si yang telah memberikan saran dan membantu dalam perbaikan tugas akhir ini. Terima kasih pula penulis ucapkan kepada pihak - pihak yang telah membantu dalam penyusunan penelitian.

\section{DAFTAR PUSTAKA}

APHA (American Public Health Association). 1989. Standar Methods for The Examinination of Water Waste. American Public Health Association (APHA), American Water Works Association (AWWA), and Water Pollution Control Federation (WPFC) 17 $7^{\text {th }}$ d., APHA, Washington D.C., 1193 p.

Basmi, J. 2000. Planktonologi: Sebagai Indikator Pencemaran Perairan. Fakultas Perikanan dan Ilmu Kelautan. Institut Pertanian Bogor. Bogor.

Boney, A.D. 1979. Phytoplankton Studies in Biology No 52. Edward Arnold, University of Glasgow, Great Britain, $116 \mathrm{p}$.

Effendi, H. 2003. Telaah Kualitas Air Bagi Pengelolaan Sumber Daya dan Lingkungan Perairan. Penerbit Kanisius. Yogyakarta. $258 \mathrm{hlm}$.

Handoko, M. Yusuf dan S.Y. Wulandari. 2013. Sebaran Nitrat dan Fosfat Dalam Kaitannya dengan Kelimpahan Fitoplankton di Kepulauan Karimunjawa. Buletin Oseanografi Marina, vol 2 : 48-53.

Hariyati, R., T. R. Soeprobowati dan S. Chotidjah. 2009. Persebaran Diatom Epipelik Secara Vertikal pada Ekosistem Mangrove Muara Sungai Banjir Kanal Timur Semarang. Laboratorium Ekologi dan Biosistematika Jurusan Biologi FMIPA Undip.

Hasrun, L.O., M. Kasim dan Salwiyah. 2013. Studi Biodiversitas Diatom Bentik Pada Areal Mangrove di Perairan Kecamatan Kolono Kabupaten Konawe Selatan. Jurnal Mina Laut Indonesia, 2(6):35-47.

Hutabarat, S. dan M. Evans. 2012. Pengantar Oceanografi. Penerbit Universitas Indonesia (UI- Press). Jakarta. $159 \mathrm{hlm}$.

Muchtar, M. 2012. Distribusi Zat Hara Fosfat, Nitrat dan Silikat di Perairan Kepulauan Natuna. Jurnal Ilmu dan Teknologi Kelautan Tropis, 4(2):304-317.

Nybakken, J.W. 1992. Biologi Laut Suatu Pendekatan Ekologis (diterjemahkan oleh M. Eidman, Koesoebiono, D. G. Bengen, M. Hutomo dan S. Sukardjo). PT Gramedia Pustaka Utama. Jakarta. $459 \mathrm{hlm}$.

Odum, E.P. 1993. Dasar-dasar Ekologi. Edisi Ketiga (Diterjemahkan Oleh T. Samingan). Gajah Mada University. Yogyakarta. 697 hlm. 
Pirzan, A. M. M, Utojo. M, Atmomarso. A, Tjaronge. Tangko dan Hasnawi. 2005. Potensi Lahan Budidaya Tambak dan Laut di Kabupaten Minahasa, Sulawesi Utara. Jurnal Penelitian Perikanan Indonesia. 11 (5): 43-50.

Purwanti, S., R. Hariyati dan E. Wiryani. 2012. Komunitas Plankton pada saat Pasang dan Surut di Perairan Muara Sungai Demaan Kabupaten Jepara. Laboratorium Ekologi dan Biosistematik, Universitas Diponegoro.

Risamasu, F.J.L. dan H.B. Prayitno. 2011. Kajian Zat Hara Fosfat, Nitrit, Nitrat dan Silikat di Perairan Kepulauan Matasiri, Kalimantan Selatan. Jurnal Ilmu Kelautan, 16(3):135-142.

Rudiyanti, S. 2011. Pertumbuhan Skeletonema costatum Pada Berbagai Tingkat Salinitas Media. Jurnal Saintek Perikanan, 6(2):69-76.

Sachlan, M. 1982. Planktonologi. Fakultas Perikanan dan Ilmu Kelautan Universitas Diponegoro, Semarang. 269 hlm.

Simanjuntak, M. 2006. Kadar Fosfat, Nitrat dan Silikat Kaitannya dengan Kesuburan Perairan Delta Mahakam, Kalimantan Timur. Pusat Penelitian Oseanografi Lipi. Jakarta.

Sulaiman, T. G. 2012. Struktur Komunitas Bacillariophyta (Diatom) di Area Pertambakan Marunda Cilincing, Jakarta Utara. [SKRIPSI]. Fakultas Matematika dan Ilmu Pengetahuan Alam. Universitas Indonesia. Depok.

Suryanti. 2008. Kajian Tingkat Saprobitas di Muara Sungai Morodemak pada saat Pasang dan Surut. Jurnal Saintek Perikanan, 4(1):76-83.

Widianingsih, R. Hartati, H. Endrawati dan M. Hilal. 2011. Kajian Kadar Total Lipid dan Kepadatan Nitzschia sp. yang Dikultur dengan Salinitas Yang Berbeda.

Yamaji, I. 1986. Illustrations of The Marine Plankton of Japan. Hoikusha, Japan.

Yuliana dan Tamrin. 2007. Fluktuasi dan Kelimpahan Fitoplankton di Danau Laguna Ternate Maluku Utara. Jurnal Perikanan, 9(2):288-196. 